\title{
KARAKTER JUJUR DALAM PEMBELAJARAN STATISTIK
}

\author{
Muhammad Royani
}

\begin{abstract}
Abstrak
Associated with the philosophy of education, values education goal is to humanize humans, develop human resources and form a perfect human being. Educational value must appear in every process of learning, including learning of mathematics that had only mastery of mathoriented course. Brameld (1975) said that as the education of power that emphasizes the importance of education for the development of value systems so that learners able to think, act. Conversely, when the focus of mathematics learning material substance, then the learning process in favor of knowledge of power. Learning of mathematics as it has the potential to bear the arrogance of science and widened the gap between the intellectual and moral. Mathematics teachers should be held to consider the characteristics of students who learn mathematics and the mathematics itself. Learning math has been less attention to the both characteristics, and more inclined to the same learning patterns, which describe in brief, give examples, exercises, and giving a homework assignment.

Ideally, the learning of statistic should develop the cognitive, affective and psychomotor as an essential component. Development of values and ethics in mathematics inappropriate if only positioned as a crucial component or the hidden curriculum (hidden curriculum). Values, morals and ethics should be explicit translated and enriched in every topic of learning. Through such learning, the balance between the ownership of knowledge, technological competence, moral individual and an appreciation of social values and culture can be improved.

Conclusion: (1) currently Learning statistic is as academic, but statistic has honest value as build the honest character personality; (2) ideally statistic learning have to develop cognitive, affective, and psycomotorist as essential component; (3) developing values, moral, and ethic on statitistic learning unexactly whether crucial component, because values, moral, and ethic expose and enrich to each learning.
\end{abstract}

Kata Kunci: Honest Character, Statistic, Learning 
Muhammad Royani

\section{Pendahuluan}

Pembelajaran yang dilaksanakan oleh guru tentunya dalam kerangka suatu proses pendidikan membentuk manusia yang diharapkan, yaitu "berkembangnya potensi peserta didik agar menjadi manusia yang beriman dan bertakwa kepada Tuhan Yang Maha Esa, berakhlak mulia, sehat, berilmu, cakap, kreatif, mandiri, dan menjadi warga negara yang demokratis serta bertanggung jawab". Pembelajaran matematika di sekolah sangat kental dengan tujuan kognitif yang menjadi target pembelajaran , hal ini terlihat dari formulasi tujuan dan evaluasi yang dirancang oleh guru dalam RPP. Akibatnya suasana pembelajaran terarah pada aktivitas pencapaian tujuan kognitif semata yang disebut instructional effect, tanpa memperhatikan tujuan afektif dan psikomotor yang disebut nurturent effect. Artinya pembelajaran matematika selama ini hanya mampu pada mengembangkan potensi peserta didik agar menjadi manusia yang berilmu saja. Pembelajaran idealnya mempunyai dampak terhadap pembentukan kepribadian seseorang, apapun pelajarannya dan apapun bahan ajarnya. Melihat fakta di sekolah ternyata pembelajaran yang berlangsung jauh dari harapan akan terbentuknya peserta didik yang berkarakter. Yang ada adalah terciptanya peserta didik yang memberi peluang pada kepemilikan kecerdasan intelektual.

Pembelajaran matematika memunculkan dua pertanyaan yang harus dijawab oleh guru, yaitu materi matematika apa yang akan diajarkan dan bagaimana mengajarkannya. Pertanyaan tersebut mengarahkan pada penentuan tujuan dan strategi pembelajaran. Selama ini tujuan pembelajaran matematika pada umumnya termasuk pembelajaran statistik mengacu pada sisi kognitif saja, belum menyentuh sisi afektif yang menjadi fokus pendidikan nilai dan kurang memperhatikan dampak pemilihan strategi terhadap pendidikan nilai yang masih merupakan hidden curriculum.

Menurut Alisah \& Dharmawan (2007:3) bahwa salah satu sebab utama kesulitan memahami matematika ialah karena sifatnya yang abstrak. 
Hal ini sangat kontras dengan alam pikiran kebanyakan dari kita yang terbiasa berpikir tentang objek-objek yang kongkret. Bahasa matematika adalah bahasa yang abstrak, bahasa yang dipenuhi dengan begitu banyak pelambang. Karena sifatnya yang abstrak inilah, seringkali kebanyakan orang awam mengira bahwa matematika itu tak ada hubungannya dengan dunia nyata yang kongkret. Orang menyangka bahwa matematika itu berhubungan dengan dunia lain, dunia yang sama sekali berbeda sifatnya dengan dunia kita yang nyata ini. Operasi perhitungan matematika tertentu, seperti penjumlahan, pengurangan, perkalian, dan pembagian memang berguna dalam kehidupan kita sehari-hari. Namun makna nilai dibalik simbolik bahasa matematika hampir tidak terkuak dalam proses belajar matematika di sekolah. Materi statistik sebagai bagian dari matematika juga dipahami seperti bagian-bagian lain dari matematika, yaitu sebatas pengetahuan tanpa keterkaitan dengan pembentukan sikap dan keterampilan dalam mencari, membaca, mengolah dan menyajikan data statistik. Padahal dibalik proses mencari data, mengolah data, menyajikan data, membaca data memiliki banyak makna nilai-nilai dari kehidupan manusia. Namun tidak terungkapkan nilai-nilai kemanusiaan tersebut dalam proses pembelajaran, sehingga selalu bersifat hidden.

\section{Pendidikan Karakter}

Kata karakter berasal dari kata Yunani charassein, yang berarti mengukir sehingga terbentuk sebuah pola (Bohlin dkk dalam Megawangi, 2004:25). Mempunyai akhlak mulia adalah tidak secara otomatis dimiliki oleh setiap manusia begitu ia dilahirkan, tetapi memerlukan proses panjang melalui pengasuhan dan pendidikan. Dalam istilah bahasa Arab karakter ini mirip dengan akhlak (akar kata khuluk), yaitu tabiat atau kebiasaan melakukan hal yang baik. Al Ghazali menggambarkan bahwa akhlak adalah tingkah laku seseorang yang berasal dari hati yang baik. Oleh karena itu pendidikan karakter adalah usaha aktif untuk membentuk kebiasaan baik (habit), sehingga sifat anak sudah terukir sejak kecil. Tuhan menurunkan 
petunjuk melalui para Nabi dan Rasul-Nya untuk manusia agar senantiasa berperilaku sesuai dengan yang diinginkan Tuhan sebagai wakil Tuhan di muka bumi.

Berbagai pendapat dari banyak pakar pendidikan anak, dapat disimpulkan bahwa terbentuknya karakter (kepribadian) manusia ditentukan oleh dua faktor, yaitu nature (alami atau fitrah) dan nurture (sosialisasi dan pendidikan). Agama mengajarkan bahwa setiap manusia mempunyai kecenderungan (fitrah) untuk mencintai kebaikan. Namun fitrah ini bersifat potensial, atau belum termanifestasi ketika anak dilahirkan. Conficius (filsuf Cina abad V SM) menyatakan bahwa walaupun manusia mempunyai fitrah kebaikan, namun tanpa diikuti dengan instruksi (pendidikan dan sosialisasi), maka manusia dapat berubah menjadi binatang, bahkan lebih buruk lagi (Brooks dkk dalam Megawangi, 2004:25).

Di dalam sebuah hadist Qudsi digambarkan bahwa manusia dilahirkan dalam keadaan fitrah (suci), seperti yang diriwayatkan oleh Muslim, telah berfirman Allah SWT: "Sesungguhnya aku telah menciptakan hamba-hamba-Ku dalam keadaan lurus, suci, dan bersih. Kemudian datanglah setan-setan yang menggelincirkan mereka dan menyesatkan dari kebenaran agama mereka. Dan setan-setan pun telah mengharamkan segala sesuatu bagi mereka apa-apa yang telah aku halalkan”.

Fitrah manusia menurut perspektif agama adalah cenderung kepada kebaikan ini, masih mengakui adanya pengaruh lingkungan yang dapat mengganggu proses tumbuhnya fitrah. Hal ini memberikan pembenaran perlunya faktor nurture atau lingkungan budaya, pendidikan, dan nilai-nilai yang perlu disosialisasikan kepada anak-anak. Oleh karena itu Tuhan menurunkan para Nabi/Rasul atau orang-orang bijak untuk mendidik dan mengingatkan kembali akan perlunya menjalankan prinsip-prinsip kebajikan agar manusia dapat memelihara fitrahnya (Megawangi, 2004:26). Nilainilai dasar budaya (akal-pikiran) dan kebudayaan (Perilaku, nilai, norma) 
KARAKTER JUJUR DALAM PEMBELAJARAN STATISTIK

diletakkan melalui proses sosialisasi, enkulturasi, dan internalisasi (Koentjaraningrat, 1990:227).

\section{Pembentukan Karakter Jujur melalui Pembelajaran}

Menurut Undang-Undang Republik Indonesia Nomor 20 Tahun 2003 tentang Sistem Pendidikan Nasional pasal 1 ayat 1 bahwa pendidikan adalah usaha sadar dan terencana untuk mewujudkan suasana belajar dan proses pembelajaran agar peserta didik secara aktif mengembangkan potensi dirinya untuk memiliki kekuatan spiritual keagamaan, pengendalian diri, kepribadian, kecerdasan, akhlak mulia, serta keterampilan yang diperlukan dirinya, masyarakat, bangsa dan Negara. Sedangkan pasal 1 ayat 2 mengemukakan bahwa pembelajaran adalah proses interaksi peserta didik dengan pendidik dan sumber belajar pada suatu lingkungan belajar.

Berdasarkan ayat 1 tersebut jelas sekali secara tersurat bahwa melalui pendidikan diharapkan terbentuklah manusia Indonesia yang berakhlak mulia dengan spiritual keagamaan, pengendalian diri, kepribadian, dan tidak semata-mata memiliki kecerdasan intelektual dan keterampilan yang diperlukan dirinya, masyarakat, bangsa dan Negara. Karakter jujur adalah akhlak mulia. Begitu pentingnya karakter jujur dalam menata kehidupan, Sumaatmadja (2002:22) mengatakan bahwa melalui pendidikan sangat diharapkan terbinanya "tata kehidupan yang penuh kesadaran, kesabaran, dan kejujuran”. Dengan kata lain dapat dikatakan bahwa kejujuran merupakan kata kunci dalam menata kehidupan, karena jujur merupakan gambaran manusia dalam berpikir, bersikap dan berperilaku dalam menjalani kehidupan dalam tatanan sosial dan budaya yang terus mengalami perubahan menuju kearah yang lebih baik untuk mendekati kesempurnaan dengan panduan agama.

Pendidikan adalah suatu usaha yang sadar dan sistematis dalam mengembangkan potensi peserta didik. Sedangkan karakter adalah watak, tabiat, akhlak, atau kepribadian seseorang yang terbentuk dari hasil internalisasi berbagai kebajikan (virtues) yang diyakini dan digunakan 
sebagai landasan untuk cara pandang, berpikir, bersikap dan bertindak. Kebajikan terdiri atas sejumlah nilai, moral, dan norma, seperti jujur, berani bertindak, dapat dipercaya, dan hormat kepada orang lain. Menurut Lickona (1992) bahwa pendidikan karakter menekankan kepada tiga kelompok karakter yang baik, yaitu moral knowing, moral feeling, moral action.

Sujono (1988:19-20) menyatakan bahwa dengan belajar matematika maka karakter atau watak seseorang dapat dibina atau dikembangkan. Ini terjadi karena belajar matematika dapat mengembangkan daya konsentrasi, meningkatkan kemampuan mengeluarkan pendapat dengan singkat dan tepat, berpikir rasional, dan mengambil keputusan secara tepat. Unsur-unsur kedisiplinan yang terdapat di dalam matematika ternyata merupakan sarana yang baik untuk membina dan mengembangkan karakter. Kebenaran dan kejujuran dua hal yang mendasar dalam matematika. Kejujuran dapat ditumbuhkan dengan membiasakan siswa memeriksa kembali hasil kerjanya. Jika dari hasil pemeriksaan kembali ternyata hasilnya salah, maka dengan tulus hati dan kejujuran siswa yakin bahwa ia berbuat salah. Kejujuran juga ditanamkan melalui pelajaran matematika. Dalam pelajaran ini siswa dibiasakan menyebutkan sifat, rumus, teorema yang digunakan. Ini berarti bahwa dalam diri siswa ditanamkan kebiasaan untuk mengetahui dan menghargai bantuan orang lain. Matematika adalah bidang studi penuh kebenaran dan kepastian. Bila seseorang mencintai maka ia mencintai kebenaran. Siswa yang mempelajari matematika dengan sadar atau tidak ia mempraktekkan kebenaran. Kebenaran dalam berpikir, bertutur kata, menulis dan bertindak merupakan kebaikan yang diperoleh secara tidak langsung dari belajar matematika. Cinta akan kebenaran dan kejujuran, dua nilai terpuji ini ditanamkan dalam jiwa siswa melalui pelajaran matematika.

Menurut Soedjadi (2000:66-67) bahwa pembelajaran matematika tidak hanya mengandung nilai edukasi yang bersifat mencerdaskan siswa tetapi juga nilai edukasi yang membantu membentuk pribadi siswa. 
Memang untuk dapat mengetahui apakah nilai edukasi pembentuk pribadi siswa telah tercapai tidaklah mudah, lebih-lebih dalam waktu yang singkat. Untuk itu diperlukan upaya terencana, kontinu dan pengamatan yang cukup lama. Selama ini nilai-nilai yang terkandung dalam pembelajaran matematika diharapkan akan tercapai dengan sendirinya. Melalui pembelajaran matematika diharapkan dengan sendirinya para siswa akan cermat dalam melakukan pekerjaan, akan kritis dan konsisten dalam bersikap, akan jujur dan lain sebagainya yang disebut pembelajaran bychance. Akan tetapi sekarang kita lebih memerlukan perencanaan pembelajaran matematika yang secara sengaja memasukkan pembelajaran nilai-nilai tersebut yang disebut pembelajaran by-design. Dalam pembelajaran ini perlu dilengkapi dengan tujuan domain afektif maupun psikomotor yang memerlukan instrumen pengukurnya.

Secara ideal, pembelajaran matematika semestinya mengembangkan kognisi, afeksi dan psikomotor sebagai komponen esensial. Dalam pemahaman seperti itu, maka pengembangan nilai dan etika dalam pembelajaran matematika tidak tepat lagi jika hanya diposisikan sebagai komponen krusial atau kurikulum tersembunyi (hidden curriculum). Nilai, moral dan etika harus secara eksplesit dijabarkan dan diperkaya dalam setiap topik pembelajaran. Melalui pembelajaran seperti itu, keseimbangan antara kepemilikan pengetahuan, kompetensi teknologi, moral individu dan apresiasi terhadap nilai-nilai sosial dan budaya dapat ditingkatkan.

Pembelajaran matematika perlu juga diarahkan pada pencapaian tujuan pendidikan yang berdiversifikasi. Beberapa tujuan yang harus dicapai dalam pendidikan matematika adalah membangkitkan peserta didik agar memiliki dorongan untuk tahu dan paham, memiliki kemampuan mengumpulkan data, menemukan makna, berpikir logis, memilih alternatif pilihan beserta akibatnya, memahami manusia pada posisi manusiawi, dan menghargai perbedaan pendapat. 
Muhammad Royani

Pembelajaran matematika yang disertai oleh pengembangan nilai, moral, dan etika diyakini akan mampu menumbuhkan potensi peserta didik melebihi apa yang dicapai dalam pembelajaran konvensional. Unesco (1993) mencatat bahwa pembelajaran matematika yang dilakukan secara terpadu dengan kebutuhan pendidikan nilai akan mampu merubah makna belajar dan meningkatkan kemampuan peserta didik dalam menghargai kontribusi iptek, mengembangkan minat mereka dalam belajar, dan memiliki sikap ilmiah yang jelas. Karena itu, materi pembelajaran yang dikembangkan harus sampai pada materi-materi esensial yang terkandung didalamnya. Materi esensial adalah pokok-pokok bahasan tentang matematika yang di dalamnya terkandung nilai, moral, dan etika yang harus dimiliki oleh peserta didik dan dianggap krusial andai kata hal tersebut tidak disampaikan dalam proses pembelajaran.

Pembelajaran matematika seperti telah dikemukakan di atas selain dapat memperluas cakrawala berpikir peserta didik tentang matematika, juga dapat mengembangkan kesadaran tentang nilai-nilai yang secara esensial yang terdapat didalamnya. Dengan cara demikian, maka penyelidikan tentang substansi materi matematika tidak ditempatkan sebagai akhir proses pembelajaran. Cara seperti itu sesuai apa yang dikatakan Brameld (1975) sebagai education of power yang menekankan pentingnya pendidikan untuk pengembangan sistem nilai agar peserta didik mampu berpikir, bersikap, dan bertindak lebih matang. Sebaliknya ketika pembelajaran matematika mengutamakan substansi materi dengan tidak terlalu berurusan pada kesadaran nilai, maka proses pembelajaran berpihak pada knowledge as power. Pembelajaran matematika seperti itu berpotensi untuk melahirkan arogansi keilmuan dan memperlebar celah antara intelektual dan moral.

Menurut kamus besar Bahasa Indonesia (2008), jujur artinya lurus, hati tidak berbohong, tidak curang, tulus, dan ikhlas. Sedangkan AlSyahrastani (dalam Shubhi, 2001: 129) mendefinisikan jujur adalah mewartakan tentang suatu hal sesuai dengan faktanya, sementara dusta 
adalah mengabarkan tentang suatu hal yang berbeda dengan faktanya. Jujur dalam pandangan umum menurut Kesuma (2011: 16) dimaknai adanya kesamaan antara realitas (kenyataan) dengan ucapan, dengan kata lain apa adanya. Jujur termasuk traits (sifat/karakter) yang disenangi dari sudut pandang teori kepribadian. Traits merupakan dimensi kepribadian yang berhubungan dengan respon yang bersifat relatif konsisten dan berfungsi untuk mengintegrasikan kebiasaan, sikap dan keterampilan kepada pola-pola berpikir, merasa, dan bertindak (Yusuf dan Nurihsan, 2008: 10).

Menurut Izutsu (1993:116) bahwa berbicara benar (jujur) dianggap sebagai kebajikan yang utama diantara orang-orang Arab padang pasir pada masa Jahiliyah, ini juga berlaku bagi semua bangsa. Kebajikan ini merupakan bentuk kebajikan yang dimiliki manusia yang paling umum, dengan demikian tidak menimbulkan permasalahan yang sangat penting. Namun demikian dalam Qur'an, kebajikan itu sangat istimewa, dan permasalahan ini akan dapat dipahami apabila kita mendekati masalah ini dari sisi negatifnya, yakni dosa tentang kebohongan. Kebenaran pada dasarnya merupakan hubungan sidq dan haqq, haqq menggambarkan sisi objektif dari kebenaran, dan bahasa dapat menjadi "benar" hanya apabila sesuai dengannya. Kebenaran sebagai persoalan subjektif, merupakan penggunaan bahasa sedemikian rupa sehingga sesuai dengan haqq, realitas. Masalah bicara benar menyangkut hubungan religius antara Tuhan dan manusia. Haqq dilawankan dengan batil yang artinya segala sesuatu yang pada hakikatnya kebohongan atau kesia-siaan.

Menurut Kesuma dkk (2011:16) bahwa Jujur sebagai sebuah nilai merupakan merupakan keputusan seseorang untuk mengungkapkan (dalam bentuk perasaan, kata-kata dan atau perbuatan) bahwa realitas yang ada tidak dimanipulasi dengan cara berbohong atau menipu orang lain untuk keuntungan dirinya. Dalam konteks pembangunan karakter di sekolah, kejujuran menjadi amat penting untuk menjadi karakter anak-anak Indonesia saat ini. Karakter ini dapat dilihat secara langsung dalam 
kehidupan di kelas, semisal ketika anak melaksanakan ujian. Perbuatan mencontek merupakan perbuatan yang mencerminkan anak tidak berbuat jujur kepada diri, teman, orang tua, dan gurunya. Agustian (2009: 2-3) menyatakan hasil penelitian membuktikan bahwa ketika seseorang berbohong terjadi perubahan fisiologis pada tubuhnya. Beberapa perubahan tersebut adalah pola pernapasan, tekanan darah, detak jantung yang meningkat, perubahan elektrolit pada kulit yang menunjukkan adanya keringat atau tidak, serta perubahan nada suara. Oleh karena itu "jadikanlah kebenaran sebagai tempat kembalimu, kejujuran sebagai tempat keberangkatanmu”.

Kejujuran menurut Berten (2007:142-145) merupakan suatu nilai moral, tapi kejujuran itu sendiri kosong, bila tidak diterapkan pada nilai lain, seperti nilai ekonomis karena nilai moral tidak terpisah dari nilai-nilai yang lain. Suseno (1987: 142-143) mengatakan bahwa dasar setiap usaha untuk menjadi orang kuat secara moral adalah kejujuran. Tanpa kejujuran keutamaan-keutamaan moral lainnya kehilangan nilai mereka. Bersikap jujur terhadap orang lain berarti terbuka dan wajar (fair). Terbuka tidak dimaksudkan bahwa segala pertanyaan orang lain harus kita jawab dengan selengkapnya. Wajar berarti memperlakukan orang lain menurut standarstandar yang dipergunakan orang lain terhadap diri kita sendiri sesuai dengan suara hati atau keyakinannya. Menurut Hartshorne and May (dalam Gagne, 1983:45-46) bahwa "a child who has a strong attitude of honesty may steal a penny when she thinks no one will notice". Seorang anak yang kuat sikap kejujurannya mungkin saja mencuri satu sen ketika ia berpikir tak seorangpun yang memperhatikannya. Kejujuran menurut Sumaatmadja (2002:7) merupakan keberanian menempatkan nilai-nilai akhlak dalam menyatakan dan menentukan berani di tempat yang benar, serta kesalahan seperti apa adanya sebagai pelanggaran atas kebenaran. Kejujuran dalam lingkup kehidupan pribadi sampai pada tatanan sosial, berarti jujur terhadap diri sendiri, terhadap keluarga, terhadap masyarakat yang puncaknya terhadap Al-Khalik Maha Kuasa. 
KARAKTER JUJUR DALAM PEMBELAJARAN STATISTIK

\section{Pembelajaran Statistika Membangun Karakter Jujur}

Berbicara statistik tentu membicarakan tentang data. Data yang diperoleh dari hasil pengamatan melalui perhitungan atau pengukuran haruslah data yang valid atau tepat di samping reliabel dan objektif. Valid menunjukkan derajat ketepatan, yaitu ketepatan antara data yang sesungguhnya terjadi pada objek dengan data yang disampaikan/ dikemukakan/diungkapkan/disajikan/dikatakan. Disini Nampak jelas sekali ingin mengungkapkan fakta atau mengatakan kebenaran apa adanya (secara jujur), bukan rekayasa. Apabila data yang dikatakan bukan yang sebenarnya, berarti telah terjadi kebohongan yang disampaikan, dengan kata lain datanya tidak valid. Statistik jelas mengajarkan kejujuran, baik dalam berpikir, bersikap dan bertindak/berperilaku atau menurut Lickona (1992) sebagai karakter yang baik, yaitu moral knowing, moral feeling, moral action. Bagaimana kita berpikir secara jujur untuk menyampaikan data, bersikap jujur untuk mengatakan data apa adanya, dan berperilaku jujur dalam mengungkapkan data.

Mengajarkan materi atau bahan ajar tentang penyajian dan pengolahan data pada siswa kelas VI sekolah dasar yang merupakan bagian dari pelajaran matematika tentu memiliki tujuan sebagai bekal hidup terkait dengan penguasaan ilmu dan juga nilai-nilai yang terkandung dalam materi tersebut. Menurut Na-Ayudhya (2008:41) hasil uji coba model pembelajaran nilai-nilai kemanusian terpadu (terintegrasi) di tingkat sekolah dasar menunjukkan keefektivan model dalam memunculkan nilai-nilai kemanusiaan pada diri siswa dan menyebabkan timbulnya transformasi pada diri mereka. Materi statistik disajikan pada semester gasal dan genap. Pada semester gasal mempelajari tentang:

a. Mengumpulkan dan membaca data;

b. Mengolah dan menyajikan data dalam bentuk tabel;

c. Menafsirkan sajian data.

Sedangkan pada semester genap mempelajari tentang: 
a. Menyajikan data dalam bentuk tabel dan diagram gabar, batang, dan lingkaran;

b. Menentukan rata-rata dan modus dari suatu data;

c. Mengurutkan data dan menentukan nilai tertinggi dan terendah;

d. Menafsirkan hasil pengolahan data. (Sumanto, dkk. 2008:VI)

Dengan mempelajari materi atau bahan ajar statistik tersebut diharapkan peserta didik memiliki kompetensi dalam mengumpulkan, membaca, mengolah, menyajikan, dan menafsirkan data dengan benar, baik sebagai instructional effect maupun nurturent effect. Materi statistik yang diajarkan pada siswa SD ini juga memiliki makna-makna esensial yang melekat dalam kehidupan masyarakat dan budaya manusia seperti yang dikemukakan oleh Phenix (1964:8) yaitu symbolic, emperics, esthetics, synoethics, ethics, and synoptic. Menurut Sumaatmadja (2002:109-110) Makna simbolik meliputi bahasa, matematika, termasuk juga isyarat-isyarat, upacara-upacara, tanda-tanda kebesaran, dan sebangsanya. Makna simbolik ini sangat berarti dalam kehidupan bermasyakat-berbudaya manusia. Makna empirik mencakup ilmu kealaman, hayati, kemanusiaan. Makna emperik ini mengembangkan kemampuan teoretik, konseptual, analitik, generalisasi berdasarkan fakta-fakta dan kenyataan yang dapat diamati. Makna estitik meliputi berbagai seni seperti musik, karya seni, kesenian, sastra dan sebangsanya. Kedalam kawasan makna estetik ini, termasuk halhal yang berkenaan dengan keindahan dan kehalusan, keunikan menurut persepsi subyektif berjiwa seni. Makna Sinoetik berkenaan dengan perasaan , kesan, penghayatan, dan kesadaran yang mendalam. Kedalam makna ini termasuk empati, simpati, dan sebangsanya. Makna etik berkenaan dengan aspek-aspek moral, akhlak, perilaku yang luhur, tanggungjawab dan sebangsanya. Makna sinoptik berkenaan dengan pengertian-pengertian yang terpadu dan mendalam seperti agama, filsafat, sejarah, dan hal-hal yang bernuansa spiritual. 
Materi statistik jelas sekali memiliki keenam makna seperti yang dikemukakan Phenix, yaitu semua data statistik menggunakan simbolik angka maupun gambar dalam mereprentasikan kebenaran atau kejujuran karena statistik adalah bagian dari matematika yang merupakan bahasa simbol yang memiliki makna sesuai dengan konteks objek pengamatan. Misalnya tiga puluh lima orang siswa sedang belajar matematika di kelas. Tiga puluh lima disimbolkan dengan bilangan 35, bukan yang lain karena 35 disini simbol kejujuran dari fakta yang ada. Makna empirik pada data statistik merupakan yang utama karena data yang diungkapkan harus fakta agar deskripsi maupun penarikan kesimpulan tidak salah, kalau faktanya 35 maka harus ditulis 35. Penyajian data-data statistik juga menggunakan tabel, diagram grafik, dan gambar yang memiliki kesan seni keindahan dalam mendeskripsikan tentang objek pengamatan atau memiliki makna estitik. Data yang digali atau diperoleh adalah fenomena yang terjadi dilapangan terkait dengan konteks kehidupan, artinya data-data menggambarkan atau memiliki makna kondisi objek pengamatan tentang berbagai hal seperti perasaan, kesan, penghayatan. Misalnya, ada 300 pendaftar siswa baru di SDN Mawar 7 Banjarmasin pada tahun 2011 padahal daya tampung hanya 70 siswa. Bilangan 300 memberi kesan bahwa animo atau keinginan (perasaan) masyarakat terhadap sekolah tersebut sangat tinggi. Artinya data statistik tersebut memiliki makna sinoetik. Data statistik memiliki makna etik, yakni data tersebut mengatakan apa adanya sesuai dengan keadaan objeknya, dengan kata lain data statistik memiliki makna jujur sebagai etika moral, akhlak, dan perilaku yang luhur. Data tidak pernah berbohong, hanya manusianya yang mungkin berbohong. Makna sinoptik dari data statistik memiliki pengertian atau makna yang mendalam yang berbicara tentang kebenaran fakta secara jujur, tunduk pada aturan yang maha kuasa.

Dengan demikian idealnya pembelajaran statistik dapat membangun karakter jujur pada pribadi peserta didik sebagai suatu kepribadian yang melekat pada dirinya sebagai nurturent effect, di samping 
memahami teori statistik sebagai instructional effect. Kenyataannya berdasarkan hasil observasi terhadap lima orang guru yang sedang mengajar matematika di lima sekolah dasar kota Banjarmasin, belum ada guru yang mencoba mengintegrasikan karakter atau nilai-nilai kehidupan seperti kejujuran dalam pembelajaran. Dua dari guru tersebut pada saat observasi sedang mengajar statistik, namun belum mengintegrasikan pendidikan karakter ke dalam pembelajaran, walaupun keduanya sudah mencantumkan karakter yang diharapkan ke dalam Rencana Persiapan Pembelajaran (RPP). Dari hasil wawancara terhadap kedua guru tersebut, ternyata keduanya sudah menerima sosialisasi tentang integrasi pendidikan karakter ke dalam pembelajaran. Akan tetapi guru hanya menekankan pada pemahaman materi statistik semata pada saat pembelajaran berlangsung, tanpa memperhatikan karakter yang diharapkan. Pada saat penulis observasi di salah satu kelas matematika, guru mengadakan simulasi pemilihan presiden, semua siswa diminta memilih satu dari tiga calon presiden. Pada saat itu, ada 36 siswa sebagai pemilih, namun pada rekapitulasi yang ditampilkan totalnya 39 pemilih. Tetapi tidak ada siswa atau guru yang protes terhadap ketidakcocokkan data pemilih tersebut. Padahal momen tersebut sangat tepat untuk validasi data atau membuat penyataan bahwa kita harus jujur dalam mengemukakan fakta, guru seharusnya berkomentar terhadap ketidakbenaran data yang diungkapkan. Ternyata guru tidak memanfaatkan momen penting tersebut.

\section{Kesimpulan}

Berdasarkan uraian yang telah dikemukakan, dapat dikemukakan kesimpulan sebagai berikut:

1. Statistik diajarkan selama ini hanya sebatas ilmu, padahal statistik memiliki makna nilai kejujuran sebagai pembentuk pribadi dengan karakter jujur.

2. Secara ideal pembelajaran statistik semestinya mengembangkan kognisi, afeksi, dan psikomotor sebagai komponen esensial. 
3. Pengembangan nilai, moral dan etika dalam pembelajaran statistik tidak tepat lagi jika hanya diposisikan sebagai komponen krusial, karena nilai, moral dan etika harus secara eksplisit dijabarkan dan diperkaya dalam setiap pembelajaran.

\section{Daftar Pustaka}

Al-Hasyimi, M.A. (2006). Kepribadian Seorang Muslim. Riyadh: IIPH

Alisah,E. \& Dharmawan, P.E. (2007). Filsafat Dunia Matematika. Pengantar untuk Memahami Konsep-konsep Matematika. Jakarta. Prestasi Pustaka.

Amril,M. (2005). Etika dan Pendidikan.Yogyakarta. Aditya Media, dan Pekanbaru:LSFK2P.

Bertens, K. (1994). Etika. Jakarta: Gramedia Pustaka Umum.

Departemen Pendidikan Nasional (2006). Kurikulum Tingkat Satuan Pendidikan. Jakarta: Depdiknas.

Departemen Pendidikan Nasional (2007). Peraturan Menteri Pendidikan Nasional

Republik Indonesia No.41 Tahun 2007 tentang Standar Proses untuk Satuan Pendidikan Dasar dan Menengah. Tersedia: http://www.bnspindonesia.org/ standar-proses.php.

Djahiri, Kosasih. (1996). Menelusuri Dunia Afektif untuk Moral dan Pendidikan Nilai Moral. Bandung:LPPMP.

Eck, Marcel. (1970). Lies \& Truth. New York: Macmillan.

Elias, J.J. (1989). Moral Education: Secular and religious. Florida: Robert E. Krieger Publishing Co., Inc.

Elmubarok, Z. (2007). Membumikan Pendidikan Nilai. Bandung: Alfabeta.

Furqon. (1999). Statistika Terapan untuk Penelitian. Bandung: Alfabeta.

Hudojo, H. (1988). Mengajar Belajar Matematika. Jakarta: Dirjen Dikti Depdibud.

Joyce, Bruce \& Weil, Marsha. (1980). Models of Teaching. New Jersey: John Wiley. 
Muhammad Royani

Koentjaraningrat. (1990). Pengantar Ilmu Antropologi. Jakarta: Rineka Cipta.

Lickona, T. (1992). Educating for Character. New York: Bantam Books

Mason, J dkk. (1985). Thinking Mathematically. England: Pearson Education.

Megawangi. (2004). Pendidikan Karakter. Jakarta: BPMIGAS.

Muhsetyo, Gatot dkk. (2008). Pembelajaran Matematika SD. Jakarta: Universitas Terbuka.

Phenix. (1964). Realms of Meaning. New York: Mc Graw-Hill

Soedjadi, R. (2000). Kiat Pendidikan Matematika di Indonesia (Konstatasi keadaan masa kini menuju harapan masa depan). Jakarta. Dirjen Dikti Depdiknas.

Sugiyono. (2009). Statistika untuk Penelitian. Bandung: Alfabeta.

Sujono. (1988). Pengajaran Matematika untuk Sekolah Menengah. Jakarta: Ditjen Dikti.

Sumaatmadja, N. (2002). Pendidikan Pemanusiaan Manusia Manusiawi. Bandung: CV Alfabeta.

Sumanto, dkk. (2008). Gemar Matematika 6: untuk Kelas VI SD/MI. Jakarta: Pusat Perbukuan.

Dr. H. Muhammad Royani, M.Pd.

Instansi : STKIP PGRI Banjarmasin

Email: hmroyani.@gmail.com 